\title{
Genetic Diversity Studies in Yield and its Contributing Traits in Groundnut (Arachis hypogaea L.) Genotypes using D2 Statistics
}

\author{
Shruti Koraddi ${ }^{1 *}$, V. Satyanarayana Rao ${ }^{2}$, M. Girija Rani ${ }^{3}$, B. Sreekanth ${ }^{4}$, \\ V. Manoj Kumar ${ }^{5}$ and Nafeez Umar ${ }^{6}$ \\ ${ }^{1}$ Department of GPBR, ${ }^{4}$ Department of Crop Physiology, ${ }^{5}$ Plant Pathology, ${ }^{6}$ Department of \\ Statistics and Mathematics, Agricultural College, Bapatla, ANGRAU, A.P., India \\ ${ }^{2}$ ADR, Lam, Guntur, ANGRAU, A.P., India \\ ${ }^{3}$ RARS, Maruteru, A.P., India \\ *Corresponding author
}

\begin{abstract}
A B S T R A C T
Keywords

D2 statistics,

Groundnut, Cluster,

Yield, Cluster

distance and

Percent of

contribution

Article Info

Accepted:

04 May 2019

Available Online:

10 June 2019

An experimental trial consisting of 40 groundnut genotypes, study was conducted during kharif, 2017 at Agricultural College Farm, Bapatla, to study the genetic divergence in different characters with yield and yield related traits. The genetic diversity among 40 genotypes for 15 characters was estimated by employing $\mathrm{D}^{2}$ statistic. The 40 groundnut genotypes were grouped under seven clusters. Among seven clusters, cluster I was the largest which comprising of 26 genotypes fallowed by clusters II with nine genotypes. The rest of clusters like III, IV, V, VI and VII had shown solitary in nature. The average D2 values of inter cluster distances, showed maximum distance between Cluster-IV and VI (819.41) followed by inter cluster distance (732.17) between IV and VII. It indicates that crossing between these clusters helps in production of transgressive segregates or better recombinants. Each character had their own contribution to total divergence where, the Oil content and protein content had maximum contribution of $38.59 \%$ and $30.39 \%$ respectively to the divergence of genotypes.
\end{abstract}

\section{Introduction}

Oil and fats are essential things in human diet since they supply energy; improve taste and palatability of food. Oilseed crops next to cereals in respect to production of agricultural commodities in India, Oilseeds occupy a place of prime importance in Indian economy. Groundnut (Arachis hypogaea L.) is a leading oilseed crop in India. In tropical and subtropical regions of the world it is an important oilseed crop. In India most of the farmers considered Groundnut as the most remunerative crop with relatively less chance of crop losses despite an unpredictable monsoon. In North coastal zone farming community of Andhra Pradesh, Groundnut is gaining popularity and farmers are growing groundnut by practicing high input management and is being cultivated 
throughout the year viz., Kharif, Rabi and Summer season.

Genetic diversity is the first and foremost thing for any crop improvement programme. For finding the gene source for the particular trait within the available germplasm, the evaluation of genetic diversity present in the trait is very important. So, it is pre-requisite to know the genetic diversity of the existing genotypes before conducting any crop improvement programme. To assess the genetic diversity present among the genotypes Mahalanobis (1936) D2 technique is widely used in crop improvement programmes. Therefore, the present study was carried out to evaluate 40 groundnut genotypes for the nature and magnitude of genetic diversity present in it.

\section{Materials and Methods}

An experimental study was carried out at the Agricultural college farm, Bapatla using 40 diverse genotypes obtained from various research stations which were located across Andhrapradesh viz., Agricultural Research Station, Kadiri, RARS Tirupati and RARS jagityal. The list of genotypes together with their pedigree and origin is presented in table 1. The experimental field is laid out in randomized block design with three replications during the year kharif 2017 . The experiment had plot size of $4 \times 1.2 \mathrm{~m} 2$ of each genotype having 3 rows. Row to row $30 \mathrm{~cm}$ and plant to plant $10 \mathrm{~cm}$ distance were maintained. At regular intervals weeding was carried out, and Earthing up operation was taken up after gypsum application. All the recommended practices were followed to raise a healthy crop. The following observations were recorded on five randomly selected plants per replication for each genotype for all the 15 characters viz., Days to $50 \%$ flowering, Plant height $(\mathrm{cm})$, SPAD chlorophyll meter reading (SCMR) at 60 DAS and 80 DAS, days to maturity, number of mature pods per plant, pod yield per plant $(\mathrm{g})$, harvest index, shelling percentage, kernel yield per plant $(\mathrm{g})$, hundred kernel weight $(\mathrm{g})$, oil content (\%), protein content $(\%)$, oil yield/plant(g) and hundred pod weight $(\mathrm{g})$. Except days to $50 \%$ flowering and days to maturity data were recorded on the plot basis. The genotypes were grouped into different cluster by using the Tocher's method. Average intra (diagonal) and inter-cluster distance and Cluster mean values for various yield and yield attributing characters. The relative contributions of different characters towards genetic divergence were also worked out.

\section{Results and Discussion}

The genetic diversity among 40 genotypes for 15 characters was measured by using $\mathrm{D}^{2}$ statistic. Based on $\mathrm{D}^{2}$ values, the genotypes were clustered using Tocher's method as given by Rao (1952).

\section{Group constellation}

Based on the $\mathrm{D}^{2}$ statistics 40 groundnut genotypes were grouped into seven clusters (Table 2 and Fig. 1) by using Tocher's method. The distribution of genotypes into seven clusters is presented in table 2. Among seven clusters, cluster I was the largest comprising of 26 genotypes fallowed by clusters II with 9 genotypes. The cluster III, IV, V, VI and VII are solitary in nature.

\section{Intra and inter relation of clusters}

The average D2 values of intra and inter cluster distances are given in table 3 and figure 2. Maximum difference among the genotypes within the same cluster was shown by cluster-I (80.78) and fallowed by cluster II (66.65). Some clusters like III, IV, V, VI and VII intra cluster value was zero due to solitary nature. 
Table.1 List of Genotypes together with their pedigree and origin

\begin{tabular}{|c|c|c|c|}
\hline Sl. No & Genotypes & Pedigree & Origin \\
\hline $\mathbf{1}$ & kadiri 6 & JL24 X AH316 S & ARS Kadiri \\
\hline 2 & kadiri 7 Bold & ICGV86522 X ICGVFDRS X ICGV 91172 & ARS Kadiri \\
\hline 3 & Kadiri 8 Bold & ICGV86522 X ICG 10 X ICGV 91172 & ARS Kadiri \\
\hline 4 & kadiri 9 & K-4 X Vemana & ARS Kadiri \\
\hline 5 & kadiri Harithandra & 91-57-2 X P1-47-6177 & ARS Kadiri \\
\hline 6 & K 1454 red & Vemana X Tirupai & ARS Kadiri \\
\hline 7 & K 1501 & K-4 X ICGX 930179 P2 & ARS Kadiri \\
\hline 8 & K1574 & Vemana x JSSP-6-VB & ARS Kadiri \\
\hline 9 & K1609 & K-8 X JL-24 & ARS Kadiri \\
\hline 10 & K1621 & ICGV99099 X K-4 & ARS Kadiri \\
\hline 11 & K1715 & Germplasm collections & ARS Kadiri \\
\hline 12 & K1719 & K-7 X TAG 24 & ARS Kadiri \\
\hline 13 & K1725 & K-7 X TAG 24 & ARS Kadiri \\
\hline 14 & K1735 & K-7 X JL 24 & ARS Kadiri \\
\hline 15 & K1787 & ICGX020063-F2-B1-SSD-P23-B2 & ARS Kadiri \\
\hline 16 & K1789 & ICGX020066-F2-B1-SSD-P2-B1 & ARS Kadiri \\
\hline 17 & K1800 & ICGV96176(Floriant X 2597447 XICGV88312) & ARS Kadiri \\
\hline 18 & K1805 & ICGV020047-F2-SSD-SSD-P18-B1 & ARS Kadiri \\
\hline 19 & K1811 & ICGV020055-F2-SSD-SSD-P18-B1 & ARS Kadiri \\
\hline 20 & K1812 & ICGV020055-F2-SSD-SSD-P20-B1 & ARS Kadiri \\
\hline 21 & K1813 & ICGV020055-F2-SSD-SSD-P25-B1 & ARS Kadiri \\
\hline 22 & K1847 & K-8 X K-4 & ARS Kadiri \\
\hline 23 & K1924(VGLS) & VG9521 X R 8808 & ARS Kadiri \\
\hline 24 & K1924(SB) & VG9521 X R 8808 & ARS Kadiri \\
\hline 25 & K2014 & K-9 X 3 X 155-005 & ARS Kadiri \\
\hline 26 & K2064 & K-7 X K-4 & ARS Kadiri \\
\hline 27 & K2066 & K 1468 X K-4 & ARS Kadiri \\
\hline 28 & K2075 & K-7 X TKG 19-A & ARS Kadiri \\
\hline 29 & K2077 & K-7 X ICGV99073 & ARS Kadiri \\
\hline 30 & K2104 & K-8 X ICGV99073 & ARS Kadiri \\
\hline 31 & TCGS1416 & Germplasm collections & RARS, Tirupati \\
\hline 32 & TCGS1426 & Germplasm collections & RARS, Tirupati \\
\hline 33 & TCGS1073 & Germplasm collections & RARS, Tirupati \\
\hline 34 & TCGS894 & Germplasm collections & RARS, Tirupati \\
\hline 35 & TCGS1157 & Germplasm collections & RARS, Tirupati \\
\hline 36 & Dharani & VRI 2-XTCGP-6 & RARS, Tirupati \\
\hline 37 & Narayani & JL-24 x Ah316/s & RARS, Tirupati \\
\hline 38 & Abhaya & K-134XTAG-24 & RARS, Tirupati \\
\hline 39 & TAG 24 & TGS-2 X TGE-1 & BARC Trombay, Mumbai \\
\hline 40 & JCG-88-2 & J 11 x TG (E) 1 & RARS,Jagityal \\
\hline 41 & Girnar-3 & Girnar 1 x ICGS 11 & DGR, Junagadh \\
\hline 42 & Girnar-2 & M 13 x R 33-1 & DGR, Junagadh \\
\hline
\end{tabular}


Table.2 Distribution of 40 Groundnut genotypes in different clusters based on $\mathrm{D}^{2}$ statistics

\begin{tabular}{|l|c|l|}
\hline Clusters & $\begin{array}{l}\text { No of } \\
\text { genotypes }\end{array}$ & Genotypes \\
\hline Cluster. I & 26 & $\begin{array}{l}\text { K1574, K1621, K 1501,Kadiri 8 Bold, K1735, kadiri 7 Bold, JCG-88-2, K2077, K1847, } \\
\text { K2104, K2014, K2075, K1609, K2064, K1715, K1725, TCGS1157, Dharani, kadiri 9, } \\
\text { K1811, K1800, K1924(VGLS), Narayani, K1813, TCGS1416, K1789. }\end{array}$ \\
\hline Cluster. II & 9 & $\begin{array}{l}\text { TCGS1426, Abhaya, TAG 24, K1812, K1805, K1787, kadiri 6, kadiri Harithandra, K 1454 } \\
\text { red }\end{array}$ \\
\hline Cluster. III & 1 & TCGS1073 \\
\hline Cluster. IV & 1 & TCGS894 \\
\hline Cluster. V & 1 & K1924(SB) \\
\hline Cluster. VI & 1 & K2066 \\
\hline Cluster. VII & 1 & K1719 \\
\hline
\end{tabular}

Table.3 Average intra (diagonal) and inter-cluster distance of 40 Groundnut genotypes

\begin{tabular}{|l|c|c|c|c|c|c|c|}
\hline \multicolumn{1}{|c|}{ Clusters } & Cluster. I & Cluster. II & Cluster. III & Cluster. IV & Cluster. V & Cluster. VI & Cluster. VII \\
\hline Cluster. I & $\mathbf{8 0 . 7 8}$ & $\mathbf{1 5 0 . 8 7}$ & $\mathbf{1 6 8 . 1 8}$ & $\mathbf{4 1 2 . 1 6}$ & $\mathbf{1 9 8 . 6 0}$ & $\mathbf{2 6 9 . 4 9}$ & $\mathbf{3 1 7 . 4 7}$ \\
\hline Cluster. II & & 66.65 & 166.65 & 196.02 & 165.76 & 332.43 & 280.37 \\
\hline Cluster. III & & & 0.00 & 190.90 & 106.99 & 589.98 & 618.81 \\
\hline Cluster. IV & & & & 0.00 & 185.46 & 819.41 & 732.17 \\
\hline Cluster. V & & & & & 0.00 & 668.87 & 619.74 \\
\hline Cluster. VI & & & & & & 0.00 & 107.70 \\
\hline Cluster. VII & & & & & & & 0.00 \\
\hline
\end{tabular}

Table.4 Cluster mean values for various yield and yield attributing characters

\begin{tabular}{|l|r|r|r|r|r|r|r|}
\hline \multicolumn{1}{|c|}{ Character } & Cluster. I & Cluster. II & Cluster. III & Cluster. IV & Cluster. V & \multicolumn{1}{c|}{ Cluster.VI } & \multicolumn{1}{c|}{ Cluster. VII } \\
\hline DFF & 27.12 & 25.96 & 25.33 & 26.33 & 24.67 & 29 & 26 \\
\hline PH & 45.67 & 48.21 & 44.33 & 35.53 & 55.60 & 48.07 & 48.40 \\
\hline NPP & 28.71 & 28.42 & 15.53 & 22.67 & 48.80 & 38.47 & 21.27 \\
\hline Pod Yield/Plant(g) & 30.64 & 26.18 & 19.23 & 24.07 & 31.50 & 40.37 & 25.33 \\
\hline HI & 0.53 & 0.50 & 0.65 & 0.70 & 0.38 & 0.53 & 0.62 \\
\hline 100 Pod Weight(g) & 111.12 & 91.20 & 101 & 101.83 & 88.17 & 126.33 & 118.83 \\
\hline Protein content (\%) & 25.95 & 24.89 & 25.90 & 23.70 & 25.20 & 25.90 & 25.20 \\
\hline Oil content (\%) & 46.29 & 46.30 & 48.10 & 48.30 & 48.40 & 43.40 & 43.50 \\
\hline SHP & 67.85 & 66.68 & 70.88 & 73.85 & 64.51 & 68.72 & 71.74 \\
\hline DM & 112.81 & 107.93 & 107.67 & 107.67 & 109.33 & 114 & 107.33 \\
\hline SPAD@60 DAS & 50.69 & 50.66 & 53.40 & 54.73 & 54.87 & 50.03 & 49.30 \\
\hline SPAD @80 DAS & 49.39 & 47.29 & 49.80 & 53.60 & 54.67 & 52.17 & 52 \\
\hline KY/Plant & 9.63 & 8.39 & 3.06 & 5.50 & 16.42 & 15.67 & 680 \\
\hline Oil Yield/Plant & 445.73 & 386.19 & 147 & 266 & 794.67 & 233.33 \\
\hline 100 KW & 50.34 & 40.73 & 56.77 & 42.50 & 43 & 64.50 & 62 \\
\hline
\end{tabular}

DFF=Days o 50\% flowering, $\mathrm{PH}=$ plant height $(\mathrm{cm}), \mathrm{NPP}=$ No. of mature pods per plant, $\mathrm{HI}=$ Harvest index,

$\mathrm{SHP}=$ shelling percentage, $\mathrm{DM}=$ Days to maturity, $\mathrm{KYP}=\mathrm{Kernal}$ yield per plant $(\mathrm{g}), 100 \mathrm{KW}=100 \mathrm{Kernal}$ weight 
Table.5 Relative contribution of 15 traits towards divergence in groundnut genotypes

\begin{tabular}{|l|c|c|}
\hline Source & Contribution \% & Times ranked 1st \\
\hline Days o 50\% flowering & $0 \%$ & 0 \\
\hline Plant Height (cm), & $0.13 \%$ & 1 \\
\hline No. of mature pods per plant & $2.05 \%$ & 16 \\
\hline Kernel Yield /Plant & $0.13 \%$ & 1 \\
\hline Pod Yield/Plant & $0.13 \%$ & 0 \\
\hline Harvest Index & $0 \%$ & 0 \\
\hline 100 Pod Weight(g) & $0 \%$ & 301 \\
\hline Oil content (\%) & $38.59 \%$ & 237 \\
\hline Protein content (\%) & $30.38 \%$ & 9 \\
\hline 100 Kernel Weight(g) & $1.15 \%$ & 6 \\
\hline Oil Yield/Plant(g) & $0.77 \%$ & 0 \\
\hline SPAD @60 DAS & $0 \%$ & 6 \\
\hline SPAD@80 DAS & $0.77 \%$ & 0 \\
\hline Shelling Percenage(\%) & $0 \%$ & 202 \\
\hline Days to maturity & $25.9 \%$ & \\
\hline Total & 100 & \\
\hline
\end{tabular}

Fig.1 Clustering of 40 groundnut genotypes by Tocher's method

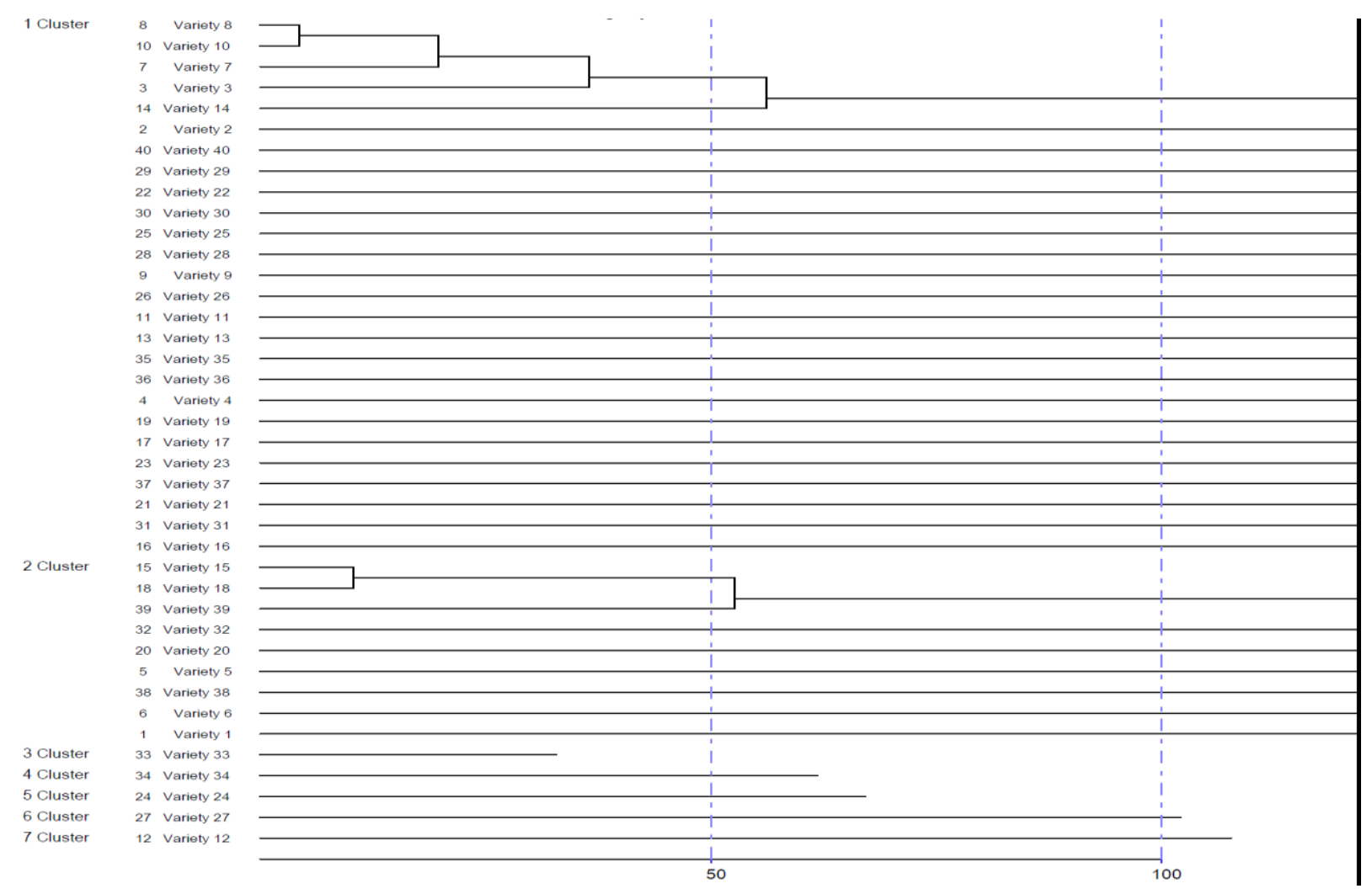


Fig.2 Average D2 values of intra and inter cluster distances

Tocher Method

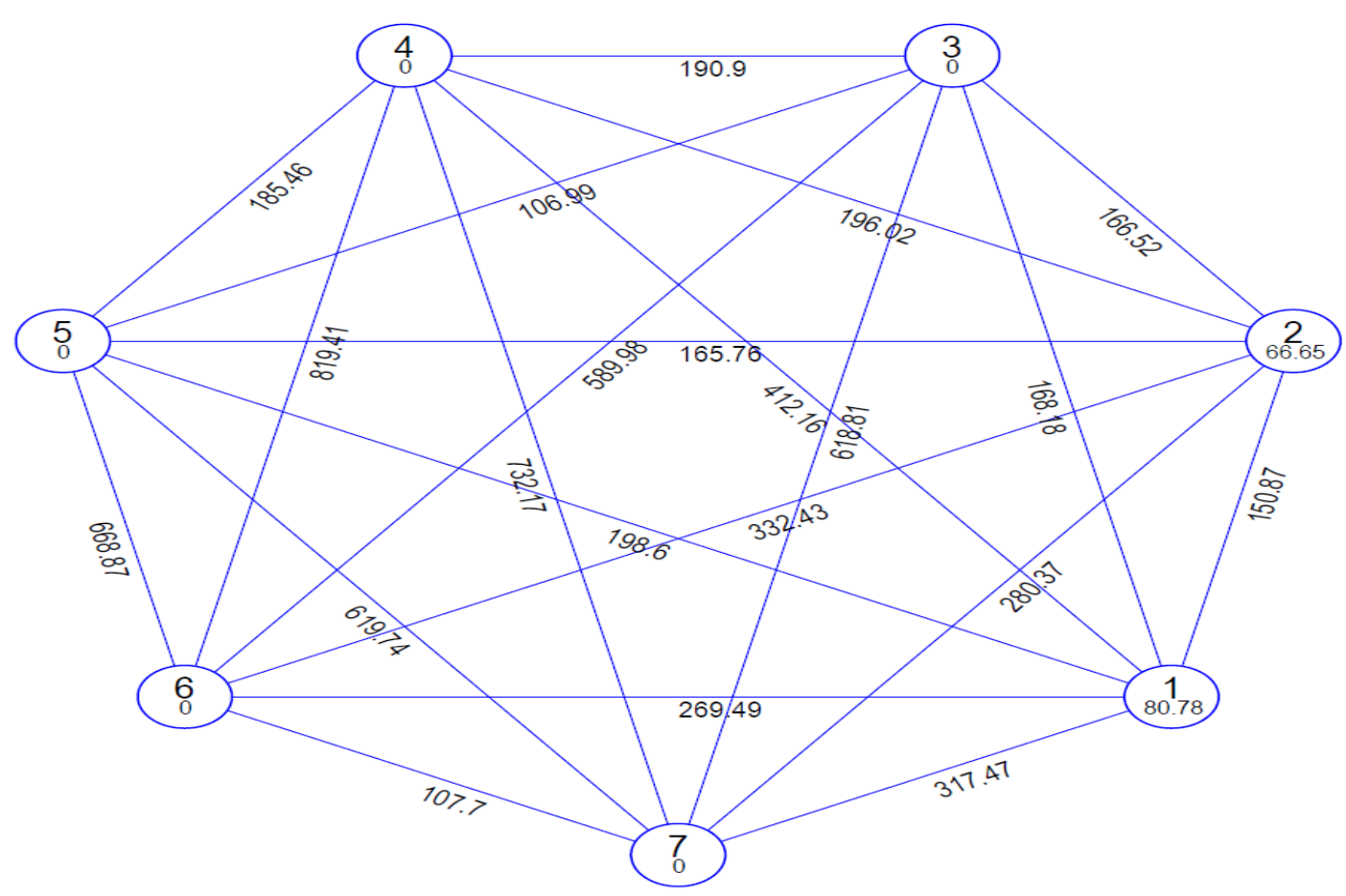

Mahalnobis Euclidean Disatnce (Not to the Scale)

Cluster-IV and VI showed maximum inter cluster distance (819.41) followed by inter cluster distance (732.17) between IV and VII (Table 3). These clusters are quite divergent from each other and the genotypes belonging to these clusters can be used as parents for hybridization programme as crosses between genotypes belonging to the clusters with maximum inter cluster distance, may give better recombinants. The lowest inter cluster distance (106.99) was noticed between cluster-III and V. Similarly Dhakar et al., (2017) and Namrata et al., (2018) also reported relatively low genetic diversity with respect to morphological characters in peanut.

\section{Cluster means}

The cluster means for 15 characters and over all character wise across the seven clusters are presented in (Table 4). All the 40 genotypes were spread over seven clusters and means of each character in each cluster were scored for all the seven clusters for all the 15 characters.

Cluster means were found highest for different characters viz., Cluster $\mathrm{V}$ showed highest mean performance for oil yield per plant (794.67), No. of mature pods/plant (48.80), plant height (55.60), days to maturity (109.33), SPAD @ DAS (54.87), SPAD @80 DAS (54.67), Kernel yield per plant (16.42) and cluster VI showed highest mean performance for Days to 50\% flowering (29) pod yield per plant (40.37), 100 pod weight (126.33), 100 kernel weight (64.50) for harvest index (0.70) and shelling percentage (73.85) cluster IV showed highest. Cluster I showed highest for protein content (25.95). 
Contribution of different characters towards divergence

Difference in proportion of contribution of each character to total D2 statistics was observed and presented in table 5. The Oil content contributed 38.59 per cent to the total divergence of genotypes followed by protein percentage $(30.38 \%)$, days to maturity (25.9\%), number of mature pods per plant (2.05\%), 100 Kernel Weight (1.15\%), both Oil Yield/Plant (g) and SPAD@80 DAS (0.77) respectively, similarly the traits like Kernel Yield /Plant, Plant Height and Pod Yield/Plant (0.13). contributed to the divergence. Some of the characters like days to 50\% flowering, SPAD @60 DAS, 100 Pod Weight $(\mathrm{g})$, Harvest Index, shelling percentage not shown their contribution to total divergence. These observations were in accordance with observations of Foundra et al., (2000) and Hampannavar and Khan. (2018).

In conclusion, the diversity is prerequisite for hybridization programme. Genotypes belonging to clusters separated by high genetic distance may be used in hybridization program to obtain a wide spectrum of variation. The most of times selecting parents only based on phenotype won't give the expected result. The selections of parents based on intra and inter cluster distance and cluster mean helps in development of transgressive segregants or better recombinants.

\section{References}

Dhakar, T.R., Sharma, H., Namrata and Bisen, P.2017.Genetic Diversity Analysis in Groundnut (Arachis hypogaea L.) Genotypes using D2 Statistics. Indian Journal of Ecology.44 (4): $175-181$.

Foundra MZ, Harnande R, Lopez L, Ravelo I. Analysis of variability in collected peanut. Legume, Res. 2000; 13:9-13.

Hampannavar, M.R and Khan, H.2018. Analysis of genetic diversity of groundnut (Arachis hypogaea L.) genotypes collected from various parts of India. Journal of Pharmacognosy and Phytochemistry; 7(2): 1100-1103.

Mahalanobis PC. On the generalized distance in statistics. Proc. Natn. Inst. Sci. India. 1936; 2: 49-55.

Namrata, Sharma, H., Bisen, P., Singh, B and Jain, S.2018. Assessment of Genetic Diversity among Groundnut (Arachis Hypogaea L.) Genotypes. International Journal of Bio-resource and Stress Management. 9(3): 383-386.

Rao CR. Advanced Statistical Methods in Biometric Research. John Wiley Sons, New York, 1952, 390.

\section{How to cite this article:}

Shruti Koraddi, V. Satyanarayana Rao, M. Girija Rani, B. Sreekanth, V. Manoj Kumar and Nafeez Umar. 2019. Genetic Diversity Studies in Yield and its Contributing Traits in Groundnut (Arachis hypogaea L.) Genotypes using D2 Statistics. Int.J.Curr.Microbiol.App.Sci. 8(06): 32-38. doi: https://doi.org/10.20546/ijcmas.2019.806.005 